\title{
Functionalized magnetic iron oxide/alginate core- shell nanoparticles for targeting hyperthermia
}

\author{
This article was published in the following Dove Press journal: \\ International Journal of Nanomedicine \\ 4 May 2015 \\ Number of times this article has been viewed
}

\author{
Shih-Hsiang Liao' \\ Chia-Hung Liu \\ Bishnu Prasad Bastakoti ${ }^{3}$ \\ Norihiro Suzuki ${ }^{7}$ \\ Yung Chang ${ }^{4}$ \\ Yusuke Yamauchi ${ }^{3}$ \\ Feng-Huei $\operatorname{Lin}^{5,6}$ \\ Kevin C-W Wu ${ }^{1,6}$ \\ 'Department of Chemical Engineering, \\ National Taiwan University No I, \\ Taipei, ${ }^{2}$ Department of Urology, \\ Taipei Medical University-Shuang Ho \\ Hospital, New Taipei City, Taiwan; \\ ${ }^{3}$ National Institute for Materials \\ Science, Ibaraki, Japan; ${ }^{4} R \& D$ Center \\ for Membrane Technology and \\ Department of Chemical Engineering, \\ Chung Yuan Christian University, \\ Taoyua, ${ }^{5}$ Institute of Biomedical \\ Engineering, National Taiwan \\ University No I, Taipei City, ${ }^{6}$ Division \\ of Medical Engineering Research, \\ National Health Research Institutes, \\ Miaoli County, Taiwan, ${ }^{7}$ International \\ Center for Young Scientists (ICYS), \\ National Institute for Materials \\ Science (NIMS), Tsukuba, Ibaraki, Japan
}

Correspondence: Kevin C-W Wu Department of Chemical Engineering, National Taiwan University, No I, Sec 4, Roosevelt Road, Taipei 10617, Taiwan Email kevinwu@ntu.edu.tw

\begin{abstract}
Hyperthermia is one of the promising treatments for cancer therapy. However, the development of a magnetic fluid agent that can selectively target a tumor and efficiently elevate temperature while exhibiting excellent biocompatibility still remains challenging. Here a new core-shell nanostructure consisting of inorganic iron oxide $\left(\mathrm{Fe}_{3} \mathrm{O}_{4}\right)$ nanoparticles as the core, organic alginate as the shell, and cell-targeting ligands (ie, D-galactosamine) decorated on the outer surface (denoted as $\mathrm{Fe}_{3} \mathrm{O}_{4} @ \mathrm{Alg}-\mathrm{GA}$ nanoparticles) was prepared using a combination of a pre-gel method and coprecipitation in aqueous solution. After treatment with an AC magnetic field, the results indicate that $\mathrm{Fe}_{3} \mathrm{O}_{4} @$ Alg-GA nanoparticles had excellent hyperthermic efficacy in a human hepatocellular carcinoma cell line (HepG2) owing to enhanced cellular uptake, and show great potential as therapeutic agents for future in vivo drug delivery systems.
\end{abstract}

Keywords: hyperthermia, iron oxide, alginate, pre-gel, targeting

\section{Introduction}

Superparamagnetic iron oxide nanoparticles (SPIONs), including magnetite $\left(\mathrm{Fe}_{3} \mathrm{O}_{4}\right)$ and maghemite $\left(\gamma-\mathrm{Fe}_{2} \mathrm{O}_{3}\right)$, have been extensively utilized in biomedical applications, including as magnetic resonance imaging contrast agents, ${ }^{1}$ for biocatalysis, ${ }^{2}$ for biological separation, ${ }^{3}$ for biosensing, ${ }^{4}$ diagnostic medical devices, ${ }^{5}$ and hyperthermia. Among these applications, hyperthermia ${ }^{6}$ is a physical therapy in which SPIONs generate heat and thus kill cancer cells when they are exposed to an external magnetic field. ${ }^{7}$ The hyperthermia of SPIONs has been considered as one of the most promising cancer therapies because it can effectively destroy cancer cells while keeping normal cells intact. The reason is that cancer cells are more sensitive to heat than normal cells..$^{8,9}$ When a high temperature (usually around $42.5^{\circ} \mathrm{C}$ ) is produced locally, tumor tissue cannot release heat energy via the bloodstream due to dysfunction of blood vessels. ${ }^{10}$ In addition, studies have also shown that cancer cells produce heat shock proteins, resulting in an increase in major histocompatibility complex class I antigens. Thus, this increases the possibility of recognition of cancer cells by cytotoxic $\mathrm{T}$ lymphocytes. ${ }^{11}$ Consequently, hyperthermia is an effective and safe cancer therapy.

One of the challenges for effective cancer therapy is how to deliver therapeutic agents to tumor sites. Most anticancer drugs cannot distinguish between cancer cells and healthy cells, which results in undesirable side effects and low efficacy. The fabrication of nanoscale drug-loading carriers has been widely studied because these nanoparticles can accumulate in tumor sites via the enhanced permeability and retention effect. ${ }^{12}$ However, such passive targeting-based drug delivery systems sometimes cause unwanted accumulation of anticancer agents in the liver, kidney, and spleen. ${ }^{13,14}$ 
In contrast with passive targeting, active targeting has attracted more attention in terms of further enhancing delivery efficacy and cancer specificity. Specific ligands (eg, folate) that can be recognized by cancer cells have been widely studied and linked to the surfaces of anticancer agents so that receptor-mediated endocytosis can occur. ${ }^{15-17}$ For example, asialoglycoprotein receptors are located on liver cancer cells and can specifically bind with glycoprotein on/in galactose residues, leading to internalization and subsequent degradation of glycoprotein inside the cells. ${ }^{18}$ Such active targeting strategies can not only effectively deliver drugs into cancer cells, but also reduce the amounts of anticancer agents used.

The combination of hyperthermia and active targeting has been regarded as one of the most promising therapies for improving anticancer efficacy. Synthesis of SPIONs and further functionalization of SPIONs with specific targeting ligands is therefore of intense research interest. So far, SPIONs have been synthesized by a coprecipitation method, ${ }^{19}$ hydrothermal treatment, ${ }^{20}$ and an organic solvent-based method. ${ }^{21}$ For example, Hyeon et al synthesized uniform and well suspended SPIONs in organic solvent systems using $\mathrm{Fe}(\mathrm{CO})_{5}$ as the precursor. ${ }^{22}$ Daou et al reported synthesis of SPIONs with a uniform particle size of $39 \mathrm{~nm}$ by hydrothermal treatment. ${ }^{23}$ Despite these pioneering works, the coprecipitation method is more acceptable because of its simple synthesis (ie, relatively low temperature and a water system). However, this method usually results in aggregated SPIONs, which are difficult to use in biomedical applications. In addition, in order for SPIONs to be functionalized with targeting ligands, the synthesized SPIONs must be reacted with the targeting ligands under the desired conditions, which is usually a complicated and time-consuming process. ${ }^{24}$ Therefore, simultaneous synthesis and functionalization of SPIONs in aqueous systems is necessary.

In this study, we developed a new synthetic approach to prepare carboxylic acid-functionalized SPIONs (ie, $\mathrm{Fe}_{3} \mathrm{O}_{4}$ ) by combination of coprecipitation of iron oxides and a pre-gel method of alginate (denoted as $\mathrm{Fe}_{3} \mathrm{O}_{4} @ \mathrm{Alg}$ nanoparticles). The $\mathrm{COOH}$-functionalized $\mathrm{Fe}_{3} \mathrm{O}_{4}$ nanoparticles were further linked with a liver cancer cell-targeting ligand (ie, galactose), denoted as $\mathrm{Fe}_{3} \mathrm{O}_{4} @$ Alg-GA nanoparticles, and used as targeted hyperthermia therapy. This new approach has several advantages: alginate has excellent biocompatibility and surface functionality (COOH group); coprecipitation of iron oxides takes place within the alginate polymer, preventing aggregation of the synthesized $\mathrm{Fe}_{3} \mathrm{O}_{4}$ nanoparticles; targeting ligands can be successfully linked on the external surface of
$\mathrm{Fe}_{3} \mathrm{O}_{4} @ \mathrm{Alg}$ nanoparticles, thereby ensuring targeting capability; and $\mathrm{Fe}_{3} \mathrm{O}_{4}$ nanoparticles with well dispersed, controllable particle sizes provide the capability for hyperthermia. We then characterized the synthesized $\mathrm{Fe}_{3} \mathrm{O}_{4} @ \mathrm{Alg}$ nanoparticles with X-ray diffraction, scanning electron microscopy (SEM), Fourier transform infrared spectroscopy (FTIR), and thermogravimetric analysis. The $\mathrm{Fe}_{3} \mathrm{O}_{4} @ \mathrm{Alg}-\mathrm{GA}$ nanoparticles showed enhanced hyperthermic efficacy when compared with $\mathrm{Fe}_{3} \mathrm{O}_{4} @ \mathrm{Alg}$ nanoparticles, which was confirmed to be the result of increased uptake of $\mathrm{Fe}_{3} \mathrm{O}_{4} @$ Alg-GA by human liver cancer (HepG2) cells (ie, the amount of $\mathrm{Fe}_{3} \mathrm{O}_{4} @$ Alg-GA nanoparticles taken up was 20 -fold greater than the amount of $\mathrm{Fe}_{3} \mathrm{O}_{4} @ \mathrm{Alg}$ nanoparticles).

\section{Materials and methods \\ Chemicals}

Iron(II) chloride tetrahydrate $\left(\mathrm{FeCl}_{2} \cdot 4 \mathrm{H}_{2} \mathrm{O}, 98 \%\right)$ was purchased from Alfa Aesar (Ward Hill, MA, USA). Iron(III) chloride hexahydrate $\left(\mathrm{FeCl}_{3} \cdot 6 \mathrm{H}_{2} \mathrm{O}\right), 1$-(3-dimethylaminopropyl)-3ethylcarbodimmide (EDC), N-hydroxysuccinimide (NHS), 3-(4,5-dimethylthiazol-2- yl)-2,5-diphenyltetrazolium bromide (MTT), potassium ferrocyanide $\left(\mathrm{K}_{4}\left[\mathrm{Fe}(\mathrm{CN})_{6}\right] \cdot 3 \mathrm{H}_{2} \mathrm{O}\right)$, $10 \%$ neutral buffered formalin, nuclear fast red counterstain, and sodium alginate were purchased from Sigma-Aldrich (St Louis, MO, USA). D-(+)-galactosamine hydrochloride was provided by Acros Organics (Thermo Fisher Scientific, Bridgewater, NJ, USA). Phosphate-buffered saline (PBS, $10 \times)$, fetal bovine serum, sodium bicarbonate (7.5 wt $\%$ ), L-glutamine (200 mM in saline), trypsin-ethylenediaminetetraacetic acid (10×), and Pen-Strep solution (penicillin 10,000 $\mathrm{U} / \mathrm{L}$ and streptomycin $10 \mathrm{mg} / \mathrm{mL}$ ) were provided by Biological Industries Israel Beit-Haemek Ltd (Beit-Haemek, Israel). CellTiter 96 Aqueous MTS Reagent Power was purchased from Promega (Madison, WI, USA). Phenazine methosulfate was purchased from AppliChem GmbH (Darmstadt, Germany).

\section{Synthesis and functionalization of $\mathrm{Fe}_{3} \mathrm{O}_{4} @$ Alg nanoparticles}

The synthesis process for $\mathrm{Fe}_{3} \mathrm{O}_{4} @ \mathrm{Alg}$ nanoparticles is described as follows. Alginate $10 \mathrm{mg}$ was dissolved in $55 \mathrm{~mL}$ of deionized (DI) water with stirring until the alginate was dissolved completely. An aqueous solution containing $\mathrm{FeCl}_{2} \cdot 4 \mathrm{H}_{2} \mathrm{O}(50 \mathrm{mM}, 10 \mathrm{~mL})$ was added to this system at a rate of $0.5 \mathrm{~mL}$ per minute and kept under stirring for 1 hour. Subsequently, another solution containing $\mathrm{FeCl}_{3} \cdot 6 \mathrm{H}_{2} \mathrm{O}$ $(62.4 \mathrm{mM}, 10 \mathrm{~mL})$ was also added to this system by the same method, and the whole system was stirred for 1 hour. 
The Fe cations $\left(\mathrm{Fe}^{2+}\right.$ and $\left.\mathrm{Fe}^{3+}\right)$ are selectively adsorbed onto the negatively charged $\mathrm{COOH}$ groups of the alginate polymer, which is a so-called pre-gel method. Next, we used an aqueous ammonia solution $(1.5 \mathrm{M})$ to adjust the $\mathrm{pH}$ of the system to 10 , in order to obtain magnetic $\mathrm{Fe}_{3} \mathrm{O}_{4}$ nanoparticles, which is a so-called coprecipitation method. After 30 minutes of stirring, the solid product was separated from the solution by a magnetic stone, washed with DI water several times, and then resuspended in DI water by sonication. We report for the first time simple and reproducible synthesis of polymer-coated magnetic nanoparticles by the combination of a pre-gel method and a coprecipitation method. Several factors, including the amount of alginate, $\mathrm{pH}$ value, and reaction time, were studied in order to control the particle size of the synthesized $\mathrm{Fe}_{3} \mathrm{O}_{4} @ \mathrm{Alg}$ nanocomposites (see discussion below).

To functionalize $\mathrm{Fe}_{3} \mathrm{O}_{4} @ \mathrm{Alg}$ nanoparticles with ligands that can specifically target cancer cells, we reacted the synthesized $\mathrm{Fe}_{3} \mathrm{O}_{4} @ \mathrm{Alg}$ nanoparticles with galactosamine via the EDC/NHS reaction, because alginate has carboxylic acid groups and galactosamine has amine groups. Typically, the $\mathrm{Fe}_{3} \mathrm{O}_{4} @ \mathrm{Alg}$ nanoparticle suspension was first diluted with PBS (pH 5) buffer to a concentration of $1.25 \mathrm{mg} / \mathrm{mL}$. Next, EDC $50 \mathrm{mg}$ and NHS $75 \mathrm{mg}$ were separately dissolved in $1 \mathrm{~mL}$ of PBS (pH 5) and the two solutions were added into $8 \mathrm{~mL}$ of $\mathrm{Fe}_{3} \mathrm{O}_{4} @ \mathrm{Alg}$ nanoparticle suspension. After the whole mixture had been stirred for 15 minutes, the EDC/ NHS-functionalized $\mathrm{Fe}_{3} \mathrm{O}_{4} @ \mathrm{Alg}$ nanoparticles were separated by a magnetic stone, washed with PBS buffer, and resuspended in $5 \mathrm{~mL}$ of PBS buffer ( $\mathrm{pH} 7.5)$. A PBS (pH 7.5) solution containing galactosamine hydrochloride $(52 \mathrm{mM}$, $5 \mathrm{~mL}$ ) was added to this solution. After 4 hours of stirring, the galactosamine-functionalized $\mathrm{Fe}_{3} \mathrm{O}_{4} @ \mathrm{Alg}$ nanoparticles (denoted as $\mathrm{Fe}_{3} \mathrm{O}_{4} @ \mathrm{Alg}-\mathrm{GA}$ nanoparticles) were separated by a magnetic stone, washed with PBS buffer $(\mathrm{pH}>9)$ several times (the basic buffer was used here to deprotonate the carboxylic acid groups of alginate), and resuspended in DI water by sonication.

\section{Characterization}

The hydrodynamic diameter and zeta potential of the synthesized $\mathrm{Fe}_{3} \mathrm{O}_{4} @ \mathrm{Alg}$ nanoparticles were measured using a Zetasizer Nano ZS system (Malvern Instruments Ltd, Malvern, UK) at $25^{\circ} \mathrm{C}$ with $\mathrm{DI} \mathrm{H}_{2} \mathrm{O}$ as the solvent. Samples were sonicated for 1 hour before measuring. The average particle size was evaluated based on dynamic light scattering. The morphology of the samples was observed using an SEM (Nova NanoSEM ${ }^{\mathrm{TM}}$, FEI, Hillsboro, NJ, USA).
The $\mathrm{Fe}_{3} \mathrm{O}_{4} @ \mathrm{Alg}$ nanoparticle suspension was sonicated for 1 hour, dropped onto copper grids (200 mesh, carboncoated), dried under vacuum, and subjected to platinum coating before observation under SEM. Functional groups of the samples were examined by FTIR (Spectrum 100, PerkinElmer, Waltham, MA, USA) at a resolution of $4 \mathrm{~cm}^{-1}$. Samples used for FTIR measurements were prepared by mixing the vacuum-dried samples with $\mathrm{KBr}$ ( $\mathrm{KBr}$ to sample, 100:1). The mixture was then ground extensively and pressed into a translucent disc. The structural properties of the samples were analyzed using an X-ray diffraction system (Ultima IV, Rigaku, Tokyo, Japan) with $\mathrm{Cu} \mathrm{K \alpha}$ radiation $(\lambda=1.5418 \AA, 40 \mathrm{kV}, 40 \mathrm{~mA})$. Thermogravimetric analysis curves were recorded on a differential scanning calorimeter (Pyris 1, PerkinElmer). Samples (5 mg) were maintained at $50^{\circ} \mathrm{C}$ for 10 minutes, then heated to $800^{\circ} \mathrm{C}$ at $10^{\circ} \mathrm{C}$ per minute, and maintained at $800^{\circ} \mathrm{C}$ for 1 minute. Nitrogen flow was fixed at $20.0 \mathrm{~mL}$ per minute throughout the measurement process. The amount of iron element inside the cells was determined using an inductively coupled plasma mass spectrometer (ICP-MS, Elan-6000, PerkinElmer) after lysis of the cells. The cells were cultured as mentioned before. The cells were transplanted into 24 wells with $5 \times 10^{4}$ per well for 1 day. After washing with PBS several times, 0.5 $\mathrm{mL}$ of solution containing $\mathrm{Fe}_{3} \mathrm{O}_{4} @ \mathrm{Alg}$ nanoparticles or $\mathrm{Fe}_{3} \mathrm{O}_{4} @ \mathrm{Alg}-\mathrm{GA}$ nanoparticles $(1 \mathrm{mg} / \mathrm{mL})$ was added into each well and the cells were cultured for another 4 hours. Each sample of $\mathrm{HCl}(12 \mathrm{M}, 0.6 \mathrm{~mL})$ was added into each well for 2 hours to dissolve the $\mathrm{Fe}_{3} \mathrm{O}_{4}$ nanoparticles. Next, $600 \mu \mathrm{L}$ of $\mathrm{HCl}(6 \mathrm{M})$ was used to wash the wells. In total, $6 \mathrm{~mL}$ of solution (five wells for each sample) was collected into a vial for measurement; one well in which cells cultured without nanoparticles was used to count the number of cells. The weight of $\mathrm{Fe}_{3} \mathrm{O}_{4}$ in each well as measured by ICP-MS and was divided by the number of cells to get the average weight of $\mathrm{Fe}_{3} \mathrm{O}_{4}$ nanoparticles inside each cell.

\section{Cell culture, viability test, and observation}

The liver cancer (HepG2) cell line was purchased from the National Health Research Institutes, Miaoli, Taiwan. HepG2 cells were incubated in flasks with Dulbecco's Modified Eagle's Medium at $37^{\circ} \mathrm{C}$ and $5 \% \mathrm{CO}_{2}$, in a $95 \%$ humidified atmosphere, and were subcultured every 3 days. Every $100 \mathrm{~mL}$ of Dulbecco's Modified Eagle's Medium was supplemented with $10 \mathrm{~mL}$ of fetal bovine serum, $2 \mathrm{~mL}$ of $\mathrm{NaHCO}_{3}$, $1 \mathrm{~mL}$ of L-glutamine, and $1 \mathrm{~mL}$ of Pen-Strep solution (penicillin 10,000 U/mL and streptomycin $10 \mathrm{mg} / \mathrm{mL}$ ). Cell viability was measured using an MTT assay. HepG2 
cells were seeded onto 96-well plates at a density of $2 \times 10^{4}$ cells per well and allowed to attach overnight. The medium was then removed, and each well was washed twice with $200 \mu \mathrm{L}$ of PBS. Media containing samples with various concentrations were added to each well, and the cells were incubated at $37^{\circ} \mathrm{C}$ for 24 hours. The medium was then removed, and the wells were washed twice with $0.2 \mathrm{~mL}$ of PBS. To each well, $20 \mu \mathrm{L}$ of MTT solution $(5 \mathrm{mg} / \mathrm{mL}$ in the DI water) was added, and the cells were incubated for an additional 4 hours. The medium was then replaced with $150 \mu \mathrm{L}$ of dimethyl sulfoxide. The plates were left stationary for 4 hours to dissolve the blue crystals, and the absorbance was recorded by a microplate reader at a wavelength of $570 \mathrm{~nm}$. Cell viability was expressed as the average absorbance of treated samples relative to untreated ones. HepG2 cells were seeded onto four-well Lab-Tek slides at a density of $1 \times 10^{5}$ cells per well. After incubation at $37^{\circ} \mathrm{C}$ with $5 \% \mathrm{CO}_{2}$ overnight, the medium was removed, and the slides were washed twice with PBS. To each well, $0.25 \mathrm{~mL}$ of DI water containing $\mathrm{Fe}_{3} \mathrm{O}_{4} @ \mathrm{Alg}$ samples $(1 \mathrm{mg} / \mathrm{mL})$ and $0.25 \mathrm{~mL}$ of Dulbecco's Modified Eagle's Medium were added. After incubation for an additional 4 hours, the supernatant was removed, and the slides were washed extensively with PBS. Next, $1 \mathrm{~mL}$ of neutral buffered formalin (10\%) was added to each well. After 12 hours, the neutral buffered formalin was replaced with Prussian Blue staining reagent $[20 \% \mathrm{HCl}(\mathrm{aq})$ and $\left.10 \% \mathrm{~K}_{4} \mathrm{Fe}(\mathrm{CN})_{6}(\mathrm{aq})\right]$. After reaction for 20 minutes, the reagent was removed, and the slides were washed with DI water three times. After removal of DI water, $500 \mu \mathrm{L}$ of nuclear fast red counter stain was added and reacted for 5 minutes. Finally, the slides were washed completely with DI water and placed on an optical microscope (Eclipse-80i, Nikon, Tokyo, Japan). The red and pink colors were produced from nuclei and cytoplasm, respectively, and the blue color was emitted from samples containing $\mathrm{Fe}_{3} \mathrm{O}_{4}$.

\section{Magnetic thermal properties and in vitro hyperthermia}

Room temperature magnetization curves of the samples were measured as a function of the applied magnetic field $(\mathrm{H})$ with a superconducting quantum interference device (SQUID, MPMS7, Quantum Design, Tokyo, Japan). The hysteresis loop of the magnetization was obtained by changing the magnetic field between $+20,000$ and $-20,000$ gauss at $37^{\circ} \mathrm{C}$. Magnetic thermal properties were examined with an alternating magnetic field heating system. The experiment was performed inside a copper coil providing an alternating magnetic field at a fixed frequency of $780 \mathrm{kHz}$ and a fixed amplitude of
19 kA/m. Samples containing $\mathrm{Fe}_{3} \mathrm{O}_{4} @ \mathrm{Alg}$ nanoparticles were first diluted to a final concentration of 0.5 mg Fe $\mathrm{O}_{4} @ \mathrm{Alg}$ nanoparticles per $\mathrm{mL}$ with $\mathrm{DI}$ water. One milliliter of the sample was then added to a centrifuge tube that was then placed in the copper coil. The temperature of the sample was kept at $37^{\circ} \mathrm{C} \pm 0.5^{\circ} \mathrm{C}$ by using an isothermal pad and measured by a thermocouple fiber. The increased temperature versus time dependence was measured for all samples. The specific absorption rate (SAR) was defined as follows:

$$
S A R=\left(\frac{C_{\text {water }}}{c}\right) d T / d t
$$

where $\mathrm{C}_{\text {water }}$ is the specific heat capacity of water and has a numeric value corresponding to $4,185 \mathrm{~J} \mathrm{~L} / \mathrm{K}$ and $\mathrm{c}$ is the sample concentration in $\mathrm{g} / \mathrm{L}$.

The in vitro effects of the hyperthermia treatments were evaluated by a proliferation assay. HepG2 cells were first cultured as described in the section on cell culture, viability test, and observation. A total of $1 \times 10^{5}$ cells were harvested in 24 wells for 1 day; $500 \mu \mathrm{L}$ of suspension containing $\mathrm{Fe}_{3} \mathrm{O}_{4} @ \mathrm{Alg}$ nanoparticles or $\mathrm{Fe}_{3} \mathrm{O}_{4} @ \mathrm{Alg}-\mathrm{GA}$ nanoparticles at a concentration of $0.5 \mathrm{mg} / \mathrm{mL}$ was then added to each well. The cells were cultured for another 4 hours, and then trypsinized and moved to a centrifuge tube. Fresh culture medium was added into the centrifuge tube to achieve $0.4 \mathrm{~mL}$ as the total volume. Three centrifuge tubes, including one control sample (without $\mathrm{Fe}_{3} \mathrm{O}_{4} @ \mathrm{Alg}$ nanoparticles) and two experimental samples (with $\mathrm{Fe}_{3} \mathrm{O}_{4} @ \mathrm{Alg}$ and $\mathrm{Fe}_{3} \mathrm{O}_{4} @$ Alg-GA nanoparticles), were put in the copper coil at the same time, and the heating time was set to 20 minutes. In order to compare the effects of the magnetic field, cells (both with and without $\mathrm{Fe}_{3} \mathrm{O}_{4} @ \mathrm{Alg}$ nanoparticles and $\mathrm{Fe}_{3} \mathrm{O}_{4} @$ Alg-GA nanoparticles) without treatment by a magnetic field were also prepared. After treatment, $100 \mu \mathrm{L}$ of each sample was taken from the centrifuge tube and added to 96 -well plates. The cells were further cultured at $37^{\circ} \mathrm{C}$ with $5 \% \mathrm{CO}_{2}$ for 18 hours. Next, $20 \mu \mathrm{L}$ of MTS solution was added to each well, and the cells were incubated for an additional 4 hours. Absorbance at $450 \mathrm{~nm}$ was recorded using an enzyme-linked immunosorbent assay plate reader. Cell viability was expressed as the average absorbance of treated samples relative to untreated ones.

\section{Plasma clotting time and red blood cell hemolysis}

The anticoagulant activity of the synthesized $\mathrm{Fe}_{3} \mathrm{O}_{4} @ \mathrm{Alg}$ was evaluated by testing clotting time in human plasma. A $160 \mu \mathrm{L}$ volume of $100 \%$ platelet-poor plasma solution was mixed 
with each solution containing $\mathrm{Fe}_{3} \mathrm{O}_{4} @ \mathrm{Alg}$ nanoparticles $(0.5 \mathrm{mg} / \mathrm{mL}, 46 \mu \mathrm{L})$ in a 96 -well plate. The solution was then recalcified by addition of calcium chloride solution ( $1 \mathrm{M}, 4 \mu \mathrm{L})$ and shaken for 30 seconds at $37^{\circ} \mathrm{C}$. Plasma clotting time was determined as the time at which the onset of the absorbance transition occurred by reading the absorbance at $660 \mathrm{~nm}$ using a PowerWave ${ }^{\mathrm{TM}}$ microplate spectrophotometer (Bio-Tek, Winooski, VT, USA). Each clotting time is reported as the average value of repeated measurements of six samples.

Disruption of red blood cell membranes was estimated to determine the non-fouling nature of the synthesized $\mathrm{Fe}_{3} \mathrm{O}_{4} @$ Alg nanoparticles using a hemolysis assay. Red blood cells were isolated by blood centrifugation and washed three times with a $0.15 \mathrm{M}$ saline solution. In each hemolysis experiment, $10^{8}$ red blood cells were suspended in $500 \mu \mathrm{L}$ of PBS. Preparation of $500 \mu \mathrm{L}$ of red blood cell solution was followed by addition of $500 \mu \mathrm{L}$ of solution containing $\mathrm{Fe}_{3} \mathrm{O}_{4} @ \mathrm{Alg}$, which was prepared in PBS at a concentration of $20 \mathrm{mg} / \mathrm{mL}$. The $\mathrm{Fe}_{3} \mathrm{O}_{4} @ \mathrm{Alg}$ nanoparticles and red blood cell mixtures were incubated in a $37^{\circ} \mathrm{C}$ water bath for 1 hour. The mixed solution was then centrifuged for 5 minutes at 2,000 rpm to separate intact red blood cells and disrupted membranes from the solution. Absorbance of the supernatant containing the released hemoglobin was then measured at $541 \mathrm{~nm}$ using the PowerWave microplate spectrophotometer. One hundred percent hemolysis was determined by measuring the absorbance of $1 \times 10^{8}$ red blood cells with complete lysis by suspending them in DI water. The control was $1 \times 10^{8}$ red blood cells in PBS. Each hemolysis is reported as the average value of three repeated measurements with 18 samples.

\section{Results and discussion \\ Synthesis and characterization of $\mathrm{Fe}_{3} \mathrm{O}_{4} @$ Alg nanoparticles}

The synthesis process is shown in Figure 1. Both $\mathrm{FeCl}_{2}$ and $\mathrm{FeCl}_{3}$ solutions were added slowly to an alginate solution at various concentrations to induce the pre-gel state of alginate (ie, $\mathrm{Fe}^{2+}$ and $\mathrm{Fe}^{3+}$ ions interact with the carboxylate groups of alginate). An aqueous ammonia solution was then added to increase the $\mathrm{pH}$ value for formation of iron oxides (ie, coprecipitation) in alginate polymer (denoted as $\mathrm{Fe}_{3} \mathrm{O}_{4} @ \mathrm{Alg}$ nanoparticles). Because alginate consists of D-mannuronic acid (M) and L-guluronic acid (G) with highly negative charges that can interact strongly with cations such as $\mathrm{Fe}^{2+}$ and $\mathrm{Fe}^{3+}$, the pre-gel state of alginate represents the egg-box structure of alginate- $\mathrm{Fe}^{2+} / \mathrm{Fe}^{3+},{ }^{25}$ resulting in formation of nanoparticles. Complete precipitation of $\mathrm{Fe}_{3} \mathrm{O}_{4}$ is expected at basic $\mathrm{pH}$ values. ${ }^{26,27}$ Here we studied the effects of different $\mathrm{pH}$ values and amounts of alginate on the hydrodynamic diameter of the synthesized $\mathrm{Fe}_{3} \mathrm{O}_{4} @ \mathrm{Alg}$ nanoparticles. As shown in Figure 2A, Figure S1, and Table S1, as the amount of alginate increased (from 10 to $40 \mathrm{mg}$ ), the hydrodynamic diameter of the synthesized $\mathrm{Fe}_{3} \mathrm{O}_{4}$ @, $\mathrm{Alg}$ nanoparticles also increased for all three different $\mathrm{pH}$ conditions. In addition, the $\mathrm{pH}$ in the final solution also influenced the hydrodynamic diameter, ie, particle sizes were decreased when $\mathrm{pH}$ increased. This is
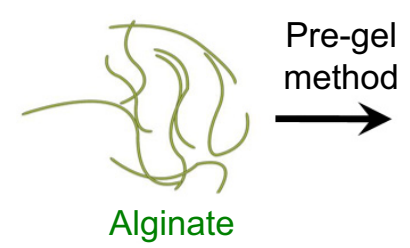

Alginat

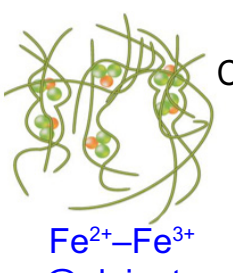

@alginate

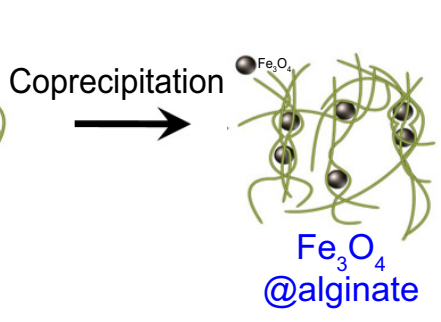

@alginate
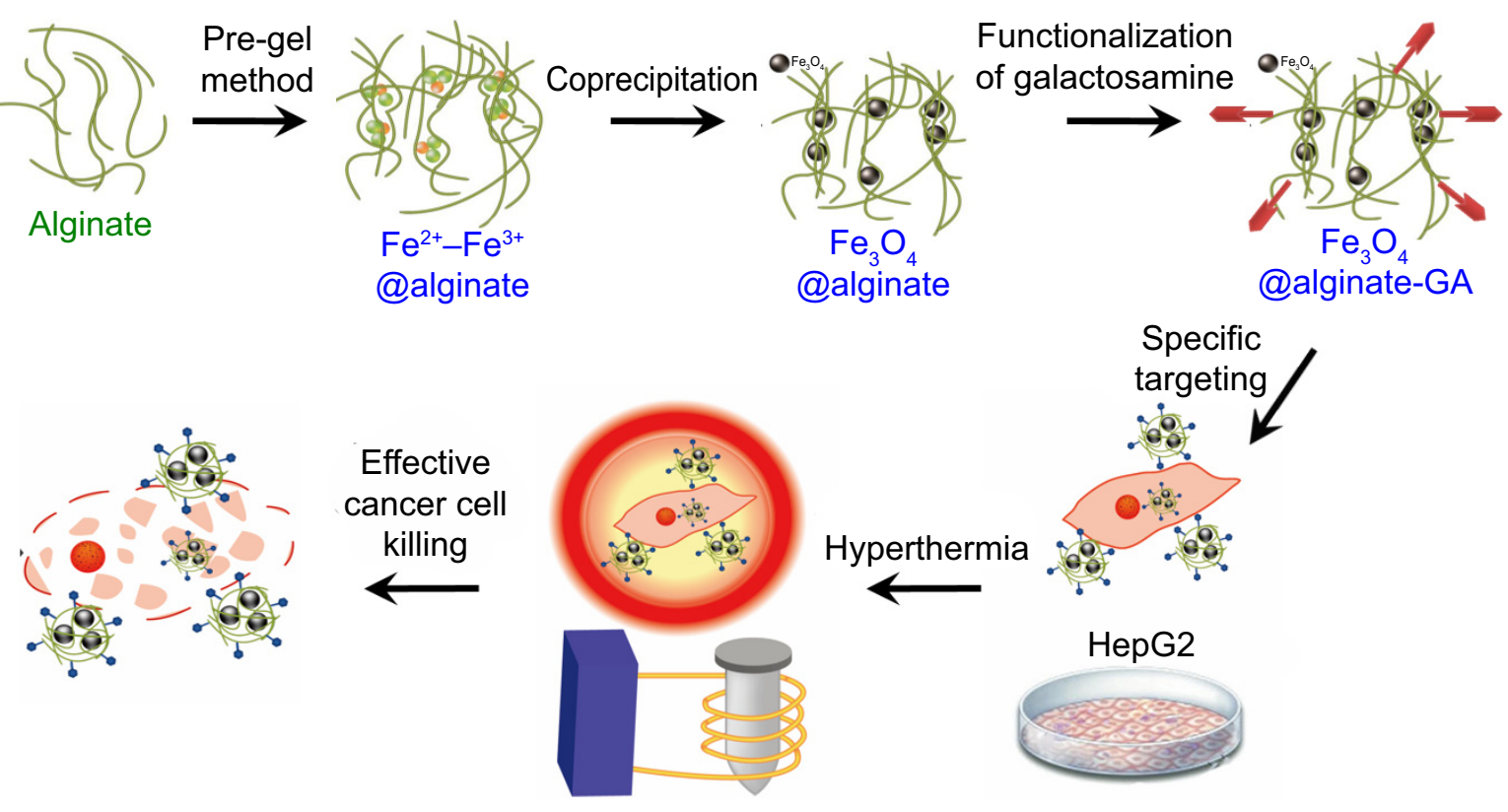

Figure I Synthesis of $\mathrm{Fe}_{3} \mathrm{O}_{4} @ \mathrm{Alg}-\mathrm{GA}$ nanoparticles for magnetic fluid hyperthermia. Abbreviations: $\mathrm{Fe}_{3} \mathrm{O}_{4}$, iron oxide; $\mathrm{Alg}$, alginate; $\mathrm{GA}$, galactosamine. 
A

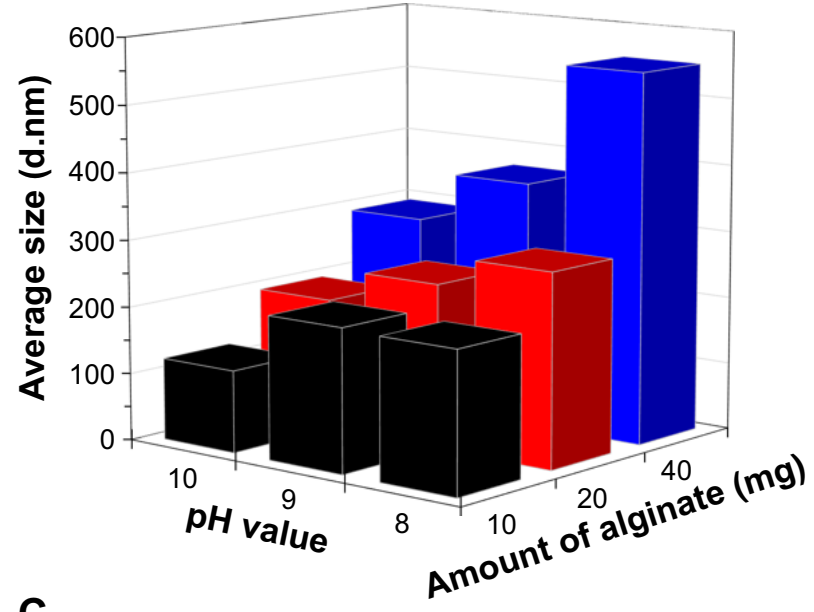

B

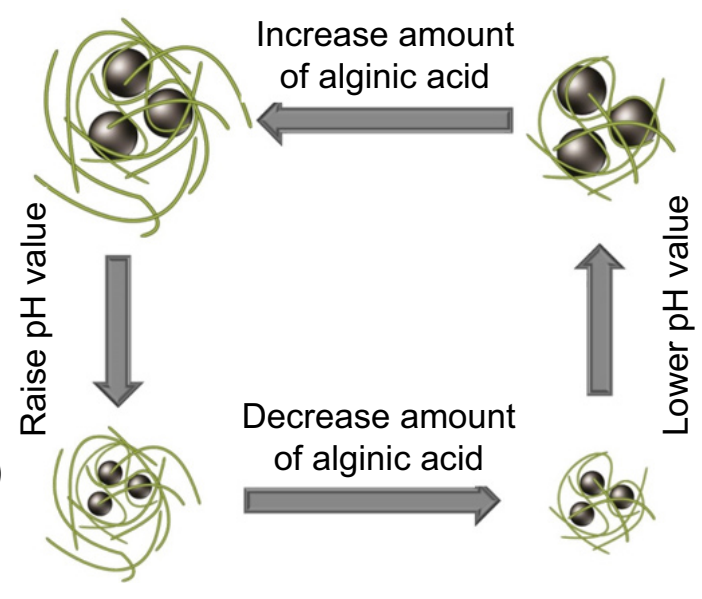

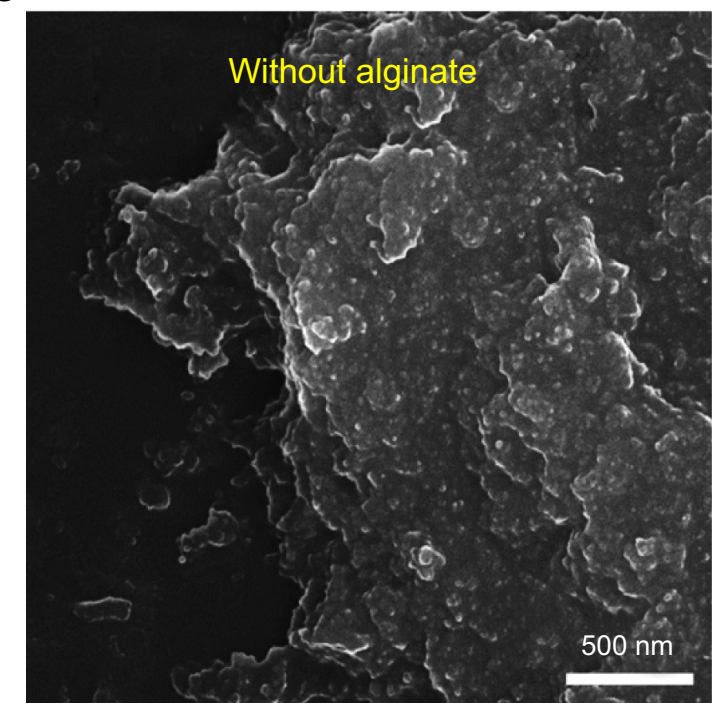
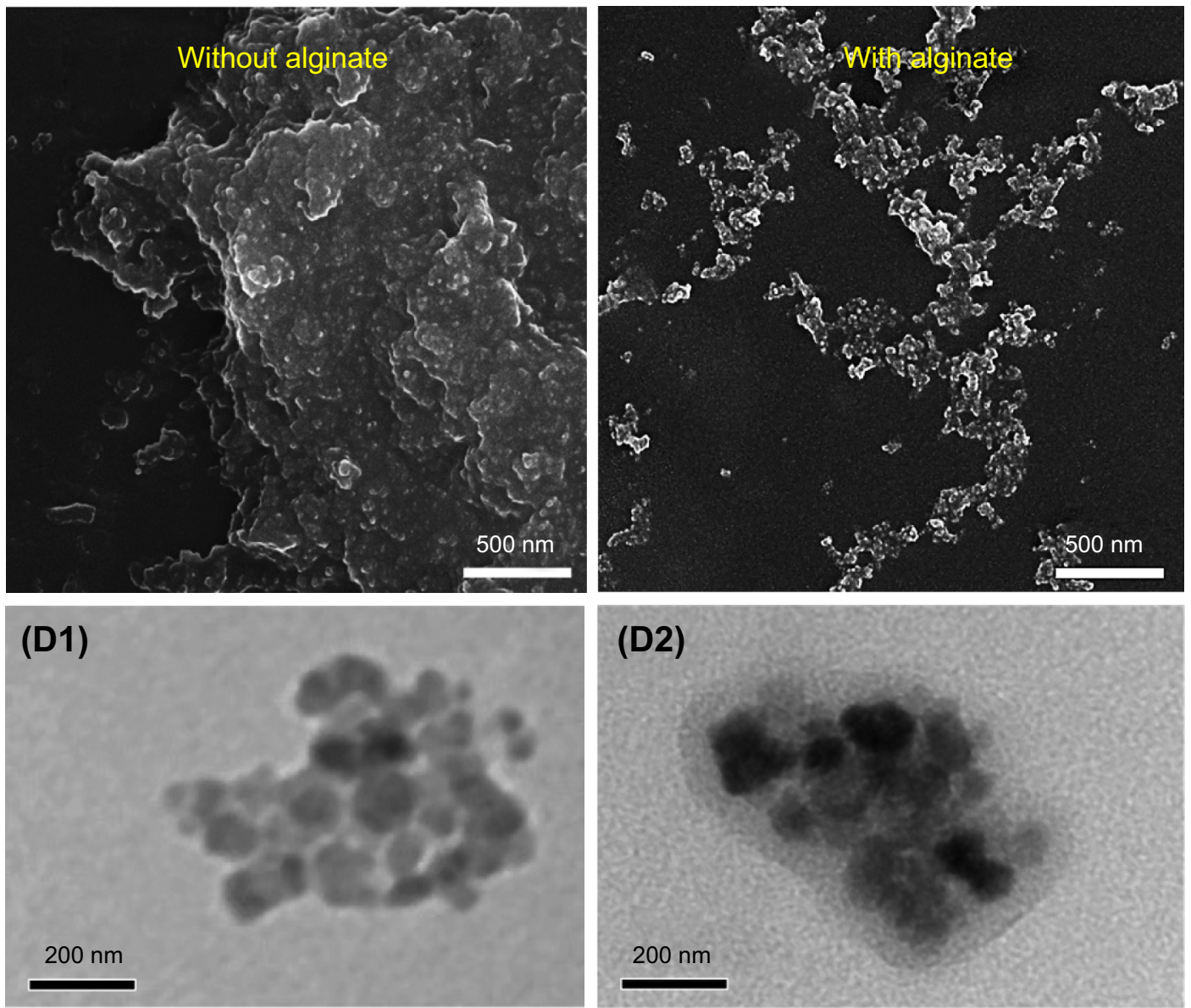

Figure $2(\mathbf{A}, \mathbf{B})$ Effects of $\mathrm{pH}$ level and amount of alginate on particle size of the synthesized $\mathrm{Fe}_{3} \mathrm{O}_{4} @ \mathrm{Alg}$ nanoparticles. (C) Scanning electron micrographs of $\mathrm{Fe}_{3} \mathrm{O}_{4}$ samples with and without the presence of alginate. (D) Transmission electron micrographs of $\mathrm{Fe}_{3} \mathrm{O}_{4}$ (DI) and $\mathrm{Fe}_{3} \mathrm{O}_{4} @ \mathrm{Alg}$ (D2) nanoparticle samples.

Abbreviations: $\mathrm{Fe}_{3} \mathrm{O}_{4}$, iron oxide; $\mathrm{Alg}$, alginate.

because $\mathrm{Fe}_{3} \mathrm{O}_{4}$ with smaller particle sizes can be synthesized at higher $\mathrm{pH}$ values, as shown in Figure 2B. Here we chose the experiment parameters of $10 \mathrm{mg}$ of alginate and $\mathrm{pH} 10$ for obtaining the optimal particle size for intravenous injection. The role of alginate is to homogeneously distribute the synthesized $\mathrm{Fe}_{3} \mathrm{O}_{4}$ nanoparticles. The SEM images in Figure 2C clearly show the different morphology of samples prepared without (left) and with (right) alginate. In the presence of alginate $10 \mathrm{mg}, \mathrm{Fe}_{3} \mathrm{O}_{4}$ displayed excellent separation owing to the abundant $\mathrm{COOH}$ groups of alginate, in contrast with the 
marked aggregation of $\mathrm{Fe}_{3} \mathrm{O}_{4}$ nanoparticles when they were synthesized in the absence of alginate. In Table 1, the sizes of $\mathrm{Fe}_{3} \mathrm{O}_{4}$ with and without alginate were 5.629 $\pm 2.257 \mathrm{~nm}$ and $122 \pm 29.5 \mathrm{~nm}$, respectively, which again indicates that alginate can prevent aggregation of $\mathrm{Fe}_{3} \mathrm{O}_{4}$. On the other hand, body temperature is about $37^{\circ} \mathrm{C}$ and the temperature of hyperthermia is $42.5^{\circ} \mathrm{C}$. The hydrodynamic diameters of nanoparticles at both body temperature and hyperthermia temperature are also important. The hydrodynamic diameters of $\mathrm{Fe}_{3} \mathrm{O}_{4} @$ Alg nanoparticles are $129 \pm 31.5 \mathrm{~nm}$ at $37^{\circ} \mathrm{C}$ and $275 \pm 77.2$ $\mathrm{nm}$ at $42.5^{\circ} \mathrm{C}$. It seems that $\mathrm{Fe}_{3} \mathrm{O}_{4} @ \mathrm{Alg}$ nanoparticles would remain at a similar particle size at $37^{\circ} \mathrm{C}$ but aggregate slightly at $42.5^{\circ} \mathrm{C}$. Slight aggregation of particles could be accepted for the in vitro experiment; however, the problem of aggregation at $42.5^{\circ} \mathrm{C}$ should be overcome in order to further apply our samples for in vivo experiment. TEM images clearly show successful alginate coating on $\mathrm{Fe}_{3} \mathrm{O}_{4}$ nanoparticles (Figure 2D). After coating with alginate, the surface charge of the samples was changed. For $\mathrm{Fe}_{3} \mathrm{O}_{4}$ nanoparticles, the surface potential was $16.1 \mathrm{mV}$ and for $\mathrm{Fe}_{3} \mathrm{O}_{4} @ \mathrm{Alg}$ nanoparticles was $-60.1 \mathrm{mV}$. The negative charge on the $\mathrm{Fe}_{3} \mathrm{O}_{4} @ \mathrm{Alg}$ nanoparticles resulted from the abundant $\mathrm{COOH}$ groups on alginate. The abundance of carboxylic groups provided a functional group for postmodification. Galactosamine is an asialoglycorprotein receptor containing an amine group which can react with the carboxylic group from alginate via EDC and NHS. At first the carboxylic group of alginate was reacted with EDC to form a highly unstable O-acylisourea, and then the NHS molecule was added to stabilize this compound. Finally, NHS-O-acylisourea, which has high reactivity toward primary amines, reacted with the amine group from galactosamine forming an amide bond between alginate and galactosamine. Post-modification of $\mathrm{Fe}_{3} \mathrm{O}_{4} @ \mathrm{Alg}$ nanoparticles with galactosamine reduced the negative potential significantly; however, the particle sizes of $\mathrm{Fe}_{3} \mathrm{O}_{4} @ \mathrm{Alg}$ nanoparticles and $\mathrm{Fe}_{3} \mathrm{O}_{4} @ \mathrm{Alg}-\mathrm{GA}$ nanoparticles were similar with each other, meaning that the particle size of $\mathrm{Fe}_{3} \mathrm{O}_{4} @ \mathrm{Alg}$ would not be affected by modification of galactosamine.

The synthesized $\mathrm{Fe}_{3} \mathrm{O}_{4}, \mathrm{Fe}_{3} \mathrm{O}_{4} @ \mathrm{Alg}$ nanoparticles, and GA-functionalized $\mathrm{Fe}_{3} \mathrm{O}_{4} @ \mathrm{Alg}$ nanoparticles were characterized with X-ray diffraction, FTIR, thermogravimetric analysis, and SQUID. As shown in Figure 3A, the X-ray diffraction patterns for $\mathrm{Fe}_{3} \mathrm{O}_{4}$ and alginate indicated a crystalline phase and an amorphous phase for $\mathrm{Fe}_{3} \mathrm{O}_{4}$ and alginate, respectively. The characteristic peaks at $2 \theta=20-70$ were the (200), (310), (400), (511), and (440) of $\mathrm{Fe}_{3} \mathrm{O}_{4}$ cubic spinel structure phase. It is worth noting that the synthesized $\mathrm{Fe}_{3} \mathrm{O}_{4} @ \mathrm{Alg}$ nanoparticles exhibited the same characteristic peaks as the above-mentioned $\mathrm{Fe}_{3} \mathrm{O}_{4}$, indicating that the synthetic method used in this study (ie, the combined coprecipitation and pre-gel methods) did not alter the crystalline phase of iron oxide. Further evidence of the formation of $\mathrm{Fe}_{3} \mathrm{O}_{4} @ \mathrm{Alg}$ nanoparticles was provided by FTIR. As shown in Figure 3B, the FTIR spectrum of $\mathrm{Fe}_{3} \mathrm{O}_{4} @$ Alg showed both of the characteristic bands from $\mathrm{Fe}_{3} \mathrm{O}_{4}$ and alginate. The stretch vibrations of $\mathrm{Fe}-\mathrm{O}$ at $577 \mathrm{~cm}^{-1}$ and $648 \mathrm{~cm}^{-1}$ were observed for $\mathrm{Fe}_{3} \mathrm{O}_{4}$, and the stretch vibrations of $\mathrm{C}-\mathrm{O}$ at $1,046 \mathrm{~cm}^{-1}$ and $1,112 \mathrm{~cm}^{-1}$ were representative of $\mathrm{C}-\mathrm{O}$ groups for alginate, the band at $1,316 \mathrm{~cm}^{-1}$ was the $\mathrm{C}-\mathrm{O}$ stretch vibration of the $\mathrm{COOH}$ group, and the peaks at $1,628 \mathrm{~cm}^{-1}$ and $1,429 \mathrm{~cm}^{-1}$ were the asymmetry and symmetry stretching vibrations, respectively, of the $\mathrm{COOH}$ group for pure alginate. ${ }^{28}$ In order to calculate the amount of alginate in the $\mathrm{Fe}_{3} \mathrm{O}_{4} @ \mathrm{Alg}$ nanoparticles, we used thermogravimetric analysis for all three samples. As shown in Figure 3C, samples were heated up to $800^{\circ} \mathrm{C}$, and the remaining weight percentages of $\mathrm{Fe}_{3} \mathrm{O}_{4}$, alginate, and $\mathrm{Fe}_{3} \mathrm{O}_{4} @ \mathrm{Alg}$ were $96.41 \%$, 30.97\%, and $91.45 \%$, respectively. Thereafter, we calculated the percentage of alginate as $7.58 \mathrm{wt} \%$ per $\mathrm{mg}$ of $\mathrm{Fe}_{3} \mathrm{O}_{4} @ \mathrm{Alg}$ nanoparticles. Finally, to ensure the efficiency of hyperthermia, the magnetic properties of the samples were analyzed with SQUID. As shown in Figure 3D, at a temperature of $310 \mathrm{~K}$, the intensity of magnetization (emu) changes with the magnetic field (Oe). All three samples, ie, $\mathrm{Fe}_{3} \mathrm{O}_{4}, \mathrm{Fe}_{3} \mathrm{O}_{4} @ \mathrm{Alg}$ nanoparticles, and $\mathrm{Fe}_{3} \mathrm{O}_{4} @$ Alg-GA nanoparticles, showed similar saturation magnetization (emu/g), ie, 66.2, 69.2, and 71.6, respectively (Table 1), indicating their superparamagnetic properties.

\section{Magnetic thermal properties and cytotoxicity of $\mathrm{Fe}_{3} \mathrm{O}_{4} @ \mathrm{Alg}$ nanoparticles}

The heating properties of the synthesized $\mathrm{Fe}_{3} \mathrm{O}_{4} @ \mathrm{Alg}$ nanoparticles were examined by measuring the increased temperature

Table I Summary of the properties of the synthesized $\mathrm{Fe}_{3} \mathrm{O}_{4}, \mathrm{Fe}_{3} \mathrm{O}_{4} @ A l g$ nanoparticles and $\mathrm{Fe}_{3} \mathrm{O}_{4} @ A l g-G A$ nanoparticles

\begin{tabular}{llllll}
\hline & $\begin{array}{l}\text { Diameter } \\
(\mathbf{n m})\end{array}$ & PDI & $\begin{array}{l}\text { Surface } \\
\text { potential }(\mathbf{m V})\end{array}$ & $\begin{array}{l}\text { Saturation } \\
\text { magnetization }(\mathbf{e m u} / \mathbf{g})\end{array}$ & $\begin{array}{l}\text { Amount of Fe } \mathbf{O}_{4} \text { in } \\
\text { cancer cell }(\mathbf{p g} / \text { cell) }\end{array}$ \\
\hline $\mathrm{Fe}_{3} \mathrm{O}_{4}$ & $5,629 \pm 2,257$ & 0.401 & +16.1 & 66.2 & - \\
$\mathrm{Fe}_{3} \mathrm{O}_{4} @ \mathrm{Alg}$ & $122 \pm 29.5$ & 0.242 & -60.1 & 69.2 & 18.5 \\
$\mathrm{Fe}_{3} \mathrm{O}_{4} @ \mathrm{Alg}-\mathrm{GA}$ & $128 \pm 18.9$ & 0.148 & -29.7 & 71.6 & 364.4 \\
\hline
\end{tabular}

Abbreviations: $\mathrm{Alg}$, alginate; $\mathrm{Fe}_{3} \mathrm{O}_{4}$, iron oxide; $\mathrm{GA}$, galactosamine; $\mathrm{PDI}$, polydispersity index. 


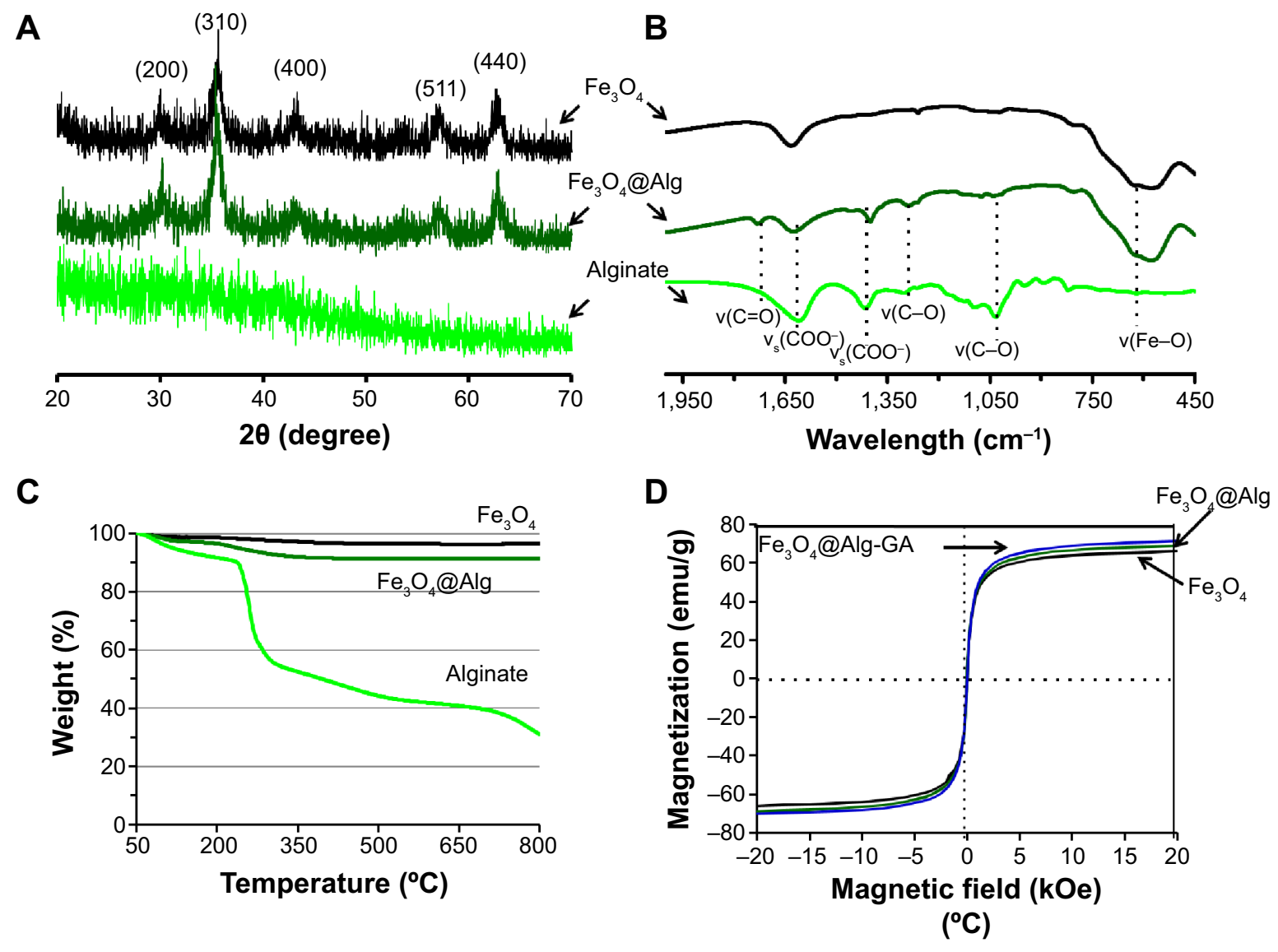

Figure 3 Characterization of alginate polymer, $\mathrm{Fe}_{3} \mathrm{O}_{4}$ nanoparticles, and $\mathrm{Fe}_{3} \mathrm{O}_{4} @ \mathrm{Alg}$ nanoparticles.

Notes: (A) X-ray diffraction pattern, (B) Fourier transform infrared spectra, (C) thermogravimetric analysis profiles, and (D) superconducting quantum interference device measurement.

Abbreviations: $\mathrm{Fe}_{3} \mathrm{O}_{4}$, iron oxide; $\mathrm{Alg}$, alginate.

upon applying a high-frequency heating instrument $(780 \mathrm{kHz}$, $19 \mathrm{kA} / \mathrm{m})$. As shown in Figure 4A, $\mathrm{Fe}_{3} \mathrm{O}_{4} @$ Alg nanoparticles could increase the temperature of water up to $10^{\circ} \mathrm{C}$ when they were exposed to a high frequency for 10 minutes. For a singledomain particle, such as the superparamagnetic particle, the external magnetic field would induce Brown relaxation and Neel relaxation to warm up the surrounding environment. Brown relaxation is described as the random rotation of the momentum through the movement of particles and Neel relaxation is described as the flipping motion of the magnetic moment relative to the particle..$^{29}$ Enpuku et $a l^{30}$ showed that Brown relaxation would be affected by aggregation of nanoparticles. The $\mathrm{Fe}_{3} \mathrm{O}_{4}$ nanoparticles (without alginate) had worse heating efficiency because they aggregated easily, thereby reducing the Brownian motion. ${ }^{31}$ The SAR equation was used to determine the heat efficiency of the samples, and the SAR value for $\mathrm{Fe}_{3} \mathrm{O}_{4}, \mathrm{Fe}_{3} \mathrm{O}_{4} @ \mathrm{Alg}$, and $\mathrm{Fe}_{3} \mathrm{O}_{4} @ \mathrm{Alg}-\mathrm{GA}$ was 192.8, 212.0, and 308.4 W/g Fe, respectively. Ma et a ${ }^{32}$ showed that SAR values of magnetite particles were size-dependent. The SAR values increased as particle size decreased. It is always important to ensure biocompatibility of newly synthesized nanomaterials. Therefore, we examined the cytotoxicity of $\mathrm{Fe}_{3} \mathrm{O}_{4} @ \mathrm{Alg}$ nanoparticles and $\mathrm{Fe}_{3} \mathrm{O}_{4} @ \mathrm{Alg}$-GA nanoparticles by MTT assay. As shown in Figure 4B, different concentrations of $\mathrm{Fe}_{3} \mathrm{O}_{4} @ \mathrm{Alg}$ nanoparticles and $\mathrm{Fe}_{3} \mathrm{O}_{4} @$ Alg-GA nanoparticles were cocultured with $\mathrm{HepG} 2$ cells for 4 hours and cell viability was measured using an ultraviolet spectrometer at $570 \mathrm{~nm}$. Cell viability was not significantly decreased even when the concentration was up to $1,000 \mu \mathrm{g} / \mathrm{mL}$, indicating excellent biocompatibility of the synthesized $\mathrm{Fe}_{3} \mathrm{O}_{4} @$ Alg-based nanoparticles and implying that they are good candidates for intracellular drug delivery. It is well known that plasma membranes have a large negative charge, meaning that the membranes would repel a nanoparticle with a negative charge. Although cationic sites are scarcer on the plasma membrane, many researchers have pointed out that the cationic sites can be used for interacting with anionic nanoparticles. ${ }^{33-35}$ The process of cell uptake could be separated into two steps, ie, binding on the membrane and internalization. Wilhelm et $\mathrm{al}^{36}$ hypothesized that electrostatic interactions governed the adsorption of anionic nanoparticles 
A

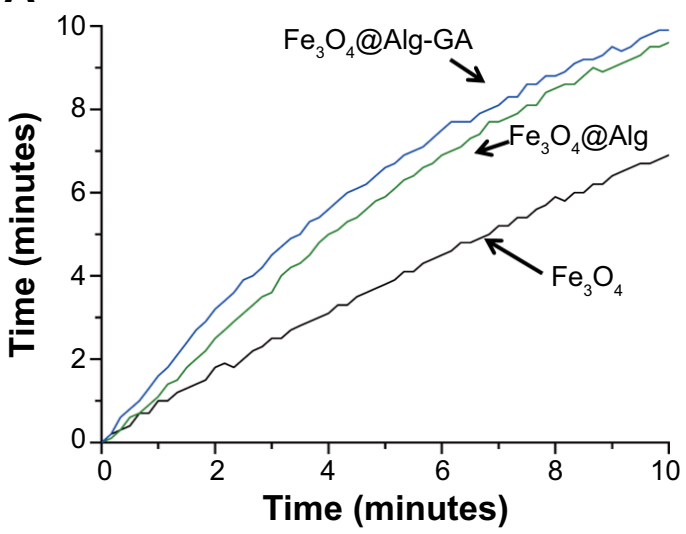

C

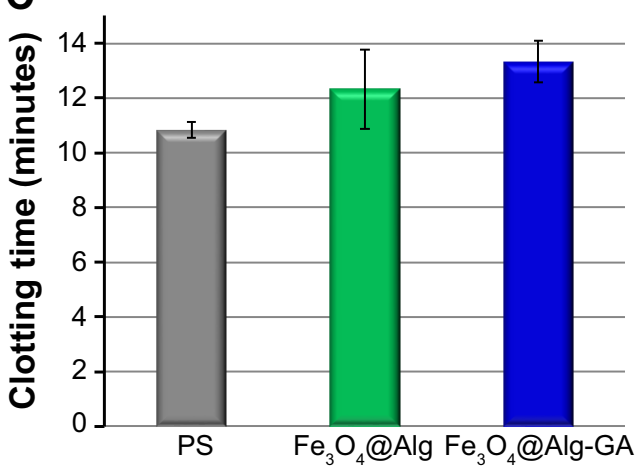

B

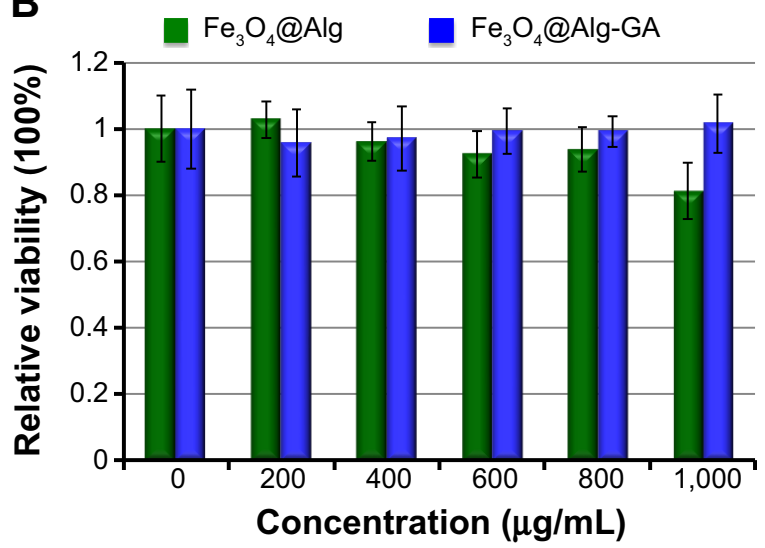

D

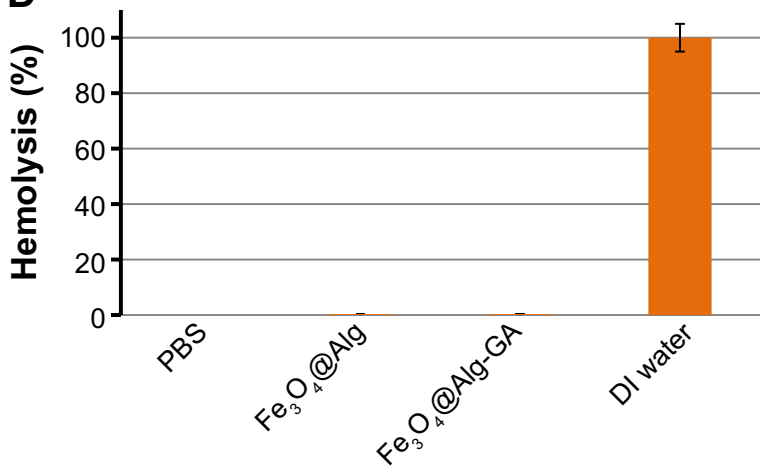

Figure 4 Hyperthermic and cytotoxic properties of the synthesized $\mathrm{Fe}_{3} \mathrm{O}_{4}$ nanoparticles, $\mathrm{Fe}_{3} \mathrm{O}_{4} @ \mathrm{Alg}$ nanoparticles, and Fe $\mathrm{O}_{4} @ \mathrm{Alg}-\mathrm{GA}$ nanoparticles.

Notes: (A) Heating properties of these three samples. (B) MTT assays of $\mathrm{HepG}_{2}$ cells treated with different concentrations of Fe $\mathrm{O}_{4} @ \mathrm{Alg}$ nanoparticles and Fe $\mathrm{O}_{4} @ \mathrm{Alg}$ GA nanoparticles. (C) Plasma clotting time of $\mathrm{Fe}_{3} \mathrm{O}_{4} @ A l g$ nanoparticles and $\mathrm{Fe}_{3} \mathrm{O}_{4} @ A$ Alg-GA nanoparticles. (D) Hemolytic activity of Fe $\mathrm{O}_{4} @ A l g$ nanoparticles and Fe $\mathrm{O}_{4} @$ Alg-GA nanoparticles.

Abbreviations: Alg, alginate; $\mathrm{DI}$, deionized; $\mathrm{Fe}_{3} \mathrm{O}_{4}$, iron oxide; $\mathrm{GA}$, galactosamine; PBS, phosphate-buffered saline; PS, polystyrene.

onto the membrane, and interacted strongly and nonspecifically with the plasma membrane. This adsorption step precedes the internalization step and governs the overall cell uptake.

We consider that the synthesized $\mathrm{Fe}_{3} \mathrm{O}_{4} @ \mathrm{Alg}$ nanoparticles and $\mathrm{Fe}_{3} \mathrm{O}_{4} @$ Alg-GA nanoparticles could be applied for in vivo hyperthermia through intravenous injection, so the hemocompatibility of the samples, including anticoagulant activity and red blood cell hemolysis, was also examined. When nanomaterials interact with plasma, plasma proteins such as fibrinogen would adsorb onto the surface of the materials, resulting in plasma clotting. ${ }^{1}$ Measurement of anticoagulant activity based on plasma clotting has already become a recognized test to estimate the compatibility between blood and a nanomaterial. The synthesized $\mathrm{Fe}_{3} \mathrm{O}_{4} @$ Alg nanoparticles and $\mathrm{Fe}_{3} \mathrm{O}_{4} @$ Alg-GA nanoparticles were directly incubated with $100 \%$ human plasma to assess the effects of direct-contact activation on plasma clotting induced by the nanomaterials as evaluated by their recalcified plasma clotting time. As shown in Figure 4C, plasma clotting time for the recalcified plasma solutions in blank polystyrene (PS) wells was determined to have an upper limit of around
11 minutes at $37^{\circ} \mathrm{C}$. The $\mathrm{Fe}_{3} \mathrm{O}_{4} @ \mathrm{Alg}$ nanoparticles and $\mathrm{Fe}_{3} \mathrm{O}_{4} @$ Alg-GA nanoparticles showed slightly prolonged plasma clotting times as well as anticoagulant activity in comparison with PS. The results indicate that the synthesized materials do not activate plasma clotting through the intrinsic coagulation pathway. A red blood cell hemolysis assay was performed to evaluate the antihemolytic activity and blood compatibility of the synthesized $\mathrm{Fe}_{3} \mathrm{O}_{4} @$ Alg-based nanoparticles. The hemolysis values for red blood cells obtained in DI water and PBS solution at $37^{\circ} \mathrm{C}$ were used as positive and negative controls, respectively. Released hemoglobin that was destroyed by the nanomaterials could be detected by measuring absorbance of $541 \mathrm{~nm}$. As shown in Figure 4D, both $\mathrm{Fe}_{3} \mathrm{O}_{4} @ \mathrm{Alg}$ nanoparticles and $\mathrm{Fe}_{3} \mathrm{O}_{4} @$ Alg-GA nanoparticles showed excellent blood compatibility like the PBS solution, indicating that our $\mathrm{Fe}_{3} \mathrm{O}_{4} @ \mathrm{Alg}$ and $\mathrm{Fe}_{3} \mathrm{O}_{4} @$ Alg-GA nanoparticles did not have any hemolytic activity (ie, they did not cause disruption of biological membranes). The results obtained here indicate that the synthesized $\mathrm{Fe}_{3} \mathrm{O}_{4} @ \mathrm{Alg}$ and $\mathrm{Fe}_{3} \mathrm{O}_{4} @$ Alg-GA nanoparticles are suitable for in vivo intravenous injection. 


\section{In vitro hyperthermia}

The morphology and viability of HepG2 cells with and without treatment with $\mathrm{Fe}_{3} \mathrm{O}_{4} @$ Alg nanoparticles and $\mathrm{Fe}_{3} \mathrm{O}_{4} @$ Alg-GA nanoparticles are shown in Figure 5A and D. Prussian blue and nuclear fast red were used to investigate the interaction between the $\mathrm{Fe}_{3} \mathrm{O}_{4} @ \mathrm{Alg}$ samples and HepG2 cells, where Prussian blue can interact with iron oxide, resulting in blue precipitates, while nuclear fast red can stain the cytoplasm and cell nucleus. As shown in Figure 5A1 and A2, intact HepG2 cells appeared to have a clear cytoplasm and a red cell nucleus. In contrast, the HepG2 cells cultured with $\mathrm{Fe}_{3} \mathrm{O}_{4} @ \mathrm{Alg}$ contained several blue precipitates in the cytoplasm, as shown in Figure 5B1 and B2. When HepG2 cells were treated with $\mathrm{Fe}_{3} \mathrm{O}_{4} @$ Alg nanoparticles bearing a HepG2-targeting ligand (ie, $\mathrm{Fe}_{3} \mathrm{O}_{4} @$ Alg-GA), there were numerous blue precipitates present in whole cells, indicating that the accumulation of $\mathrm{Fe}_{3} \mathrm{O}_{4} @ \mathrm{Alg}$ nanoparticles could be greatly enhanced by functionalization of D-galactosamine on the surface of the $\mathrm{Fe}_{3} \mathrm{O}_{4} @ \mathrm{Alg}$ nanoparticles, as shown in Figure 5 $\mathrm{C} 1$ and $\mathrm{C} 2$. However, cells that had taken up $\mathrm{Fe}_{3} \mathrm{O}_{4} @ \mathrm{Alg}$ nanoparticles still showed an elongated shape, indicating that the $\mathrm{Fe}_{3} \mathrm{O}_{4} @$ Alg nanoparticles did not harm cells in the absence of a magnetic field. This conclusion can be further supported by the high cell viability in the case of $\mathrm{Fe}_{3} \mathrm{O}_{4} @ \mathrm{Alg}$ and
$\mathrm{Fe}_{3} \mathrm{O}_{4} @$ Alg-GA nanoparticles, as shown in Figure 5D. The efficacy of hyperthermia with $\mathrm{Fe}_{3} \mathrm{O}_{4} @$ Alg nanoparticles was evaluated by comparing cell viability with and without magnetic field treatment, as shown in Figure 5D. First, when applying a magnetic field to intact cells, cell viability only decreased slightly, as compared with the case without applying a magnetic field (ie, cell [MF]). We suggest that the anticancer effect from the magnetic field can be ignored. For the case of $\mathrm{Fe}_{3} \mathrm{O}_{4} @ \mathrm{Alg}$ nanoparticles, cell viability decreased to around $60 \%$ after the magnetic field treatment (ie, $\mathrm{Fe}_{3} \mathrm{O}_{4} @ \mathrm{Alg}[\mathrm{MF}]$ ), successfully demonstrating the hyperthermia effect. This effect was significantly enhanced when the cells were treated with $\mathrm{Fe}_{3} \mathrm{O}_{4} @$ Alg-GA nanoparticles. Almost all the cells were killed (viability was only around $5 \%$ for the case of $\mathrm{Fe}_{3} \mathrm{O}_{4} @ \mathrm{Alg}-\mathrm{GA}[\mathrm{MF}]$ ). We propose that the hyperthermia effect results from the appearance of $\mathrm{Fe}_{3} \mathrm{O}_{4}$ nanoparticles inside the cells, and its efficacy should be proportional to the amount of $\mathrm{Fe}_{3} \mathrm{O}_{4}$ nanoparticles inside the cells. To verify this, we collected the cells that had taken up $\mathrm{Fe}_{3} \mathrm{O}_{4} @ \mathrm{Alg}$ nanoparticles or $\mathrm{Fe}_{3} \mathrm{O}_{4} @$ Alg-GA nanoparticles, lysed these cells, and then analyzed the amount of $\mathrm{Fe}_{3} \mathrm{O}_{4}$ inside them by ICP-MS. As shown in Table 1, the amounts of $\mathrm{Fe}_{3} \mathrm{O}_{4}$ inside the cells were $18.5 \mathrm{pg}$ and $364.43 \mathrm{pg}$ for the $\mathrm{Fe}_{3} \mathrm{O}_{4} @ \mathrm{Alg}$ nanoparticle and $\mathrm{Fe}_{3} \mathrm{O}_{4} @ \mathrm{Alg}-\mathrm{GA}$ nanoparticle groups, respectively.
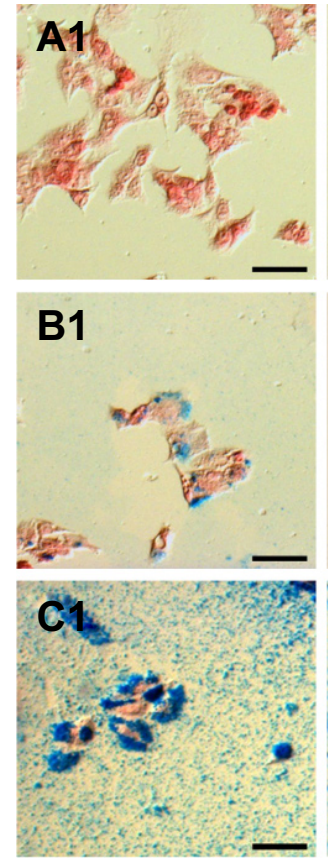

Scale bar: $50 \mu \mathrm{m}$

A2
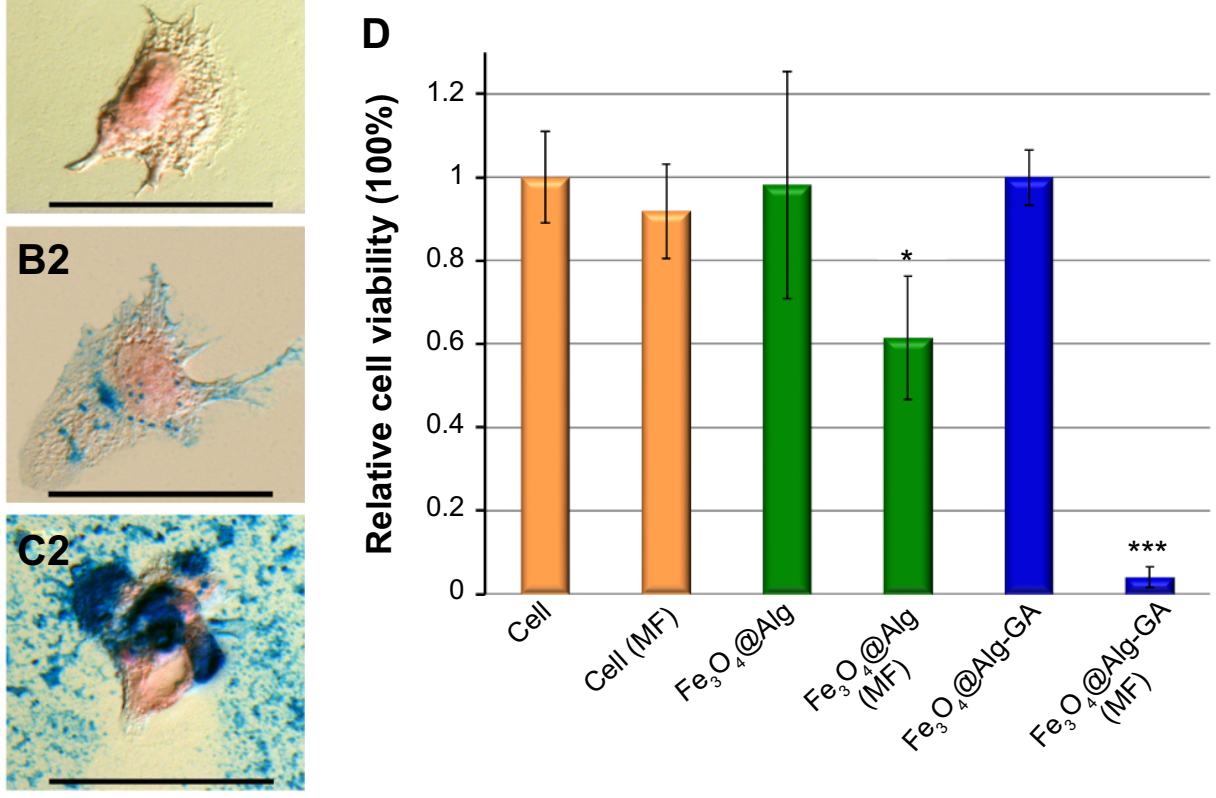

Figure 5 (A-C) Cell morphology of HepG2 cells (AI, A2) treated with Fe $\mathrm{O}_{4} @ A$ Alg nanoparticles (BI, B2) and Fe $\mathrm{O}_{4} @ A$ Alg-GA nanoparticles (CI, C2). (D) Viability of HepG2 cancer cells incubated with $\mathrm{Fe}_{3} \mathrm{O}_{4} @ A \mid g$ and $\mathrm{Fe}_{3} \mathrm{O}_{4} @ A$ Alg-GA nanoparticles with and without a magnetic field. The * and *** indicate the apparent difference of the results.

Abbreviations: Alg, alginate; $\mathrm{DI}$, deionized; $\mathrm{Fe}_{3} \mathrm{O}_{4}$, iron oxide; $\mathrm{GA}$, galactosamine; MF, magnetic field. 
This result indeed supports our hypothesis, and indicates that efficient hyperthermia could be achieved by enhanced internalization of $\mathrm{Fe}_{3} \mathrm{O}_{4}$ nanoparticles.

\section{Conclusion}

This study reports the synthesis of $\mathrm{Fe}_{3} \mathrm{O}_{4} @ \mathrm{Alg}$ nanoparticles with controllable particle sizes through the combination of coprecipitation and pre-gel methods under desired synthesis conditions. The synthesized $\mathrm{Fe}_{3} \mathrm{O}_{4} @ \mathrm{Alg}$ nanoparticles demonstrated excellent cell and blood compatibility, along with hyperthermic activity toward HepG2 cells. The abundant $\mathrm{COOH}$ groups on the external surface afford the ability to functionalize $\mathrm{Fe}_{3} \mathrm{O}_{4} @ \mathrm{Alg}$ nanoparticles with a liver cancer cell-targeting ligand (ie, D-galactosamine). $\mathrm{Fe}_{3} \mathrm{O}_{4} @$ Alg-GA nanoparticles show enhanced hyperthermia efficacy owing to their increased internalization, which shows significant potential as effective and visually observable transmembrane heat nanogenerator. Further development of these $\mathrm{Fe}_{3} \mathrm{O}_{4} @ \mathrm{Alg}$ nanoparticles with controlled drug delivery can lead to a new generation of nanodevices for biomedical applications.

\section{Acknowledgments}

This research was supported by the Ministry of Science and Technology, Taiwan (101-2628-E-002-015-MY3), National Taiwan University (102R7842, 102R7740), Center of Strategic Materials Alliance for Research and Technology, National Taiwan University (102R104100), and National Health Research Institutes of Taiwan (03A1BNMP14-014).

\section{Disclosure}

The authors report no conflicts of interest in this work.

\section{References}

1. Mayer A, Vadon M, Rinner B, Novak A, Wintersteiger R, Frohlich E. The role of nanoparticle size in hemocompatibility. Toxicology. 2009; 258(2-3):139-147.

2. Yu CH, Saadi AA, Shih SJ, Qiu L, Tam KY, Tsang SC. Immobilization of BSA on silica-coated magnetic iron oxide nanoparticle. J Phys Chem. 2009;113(2):537-543.

3. Yu X, Wan J, Shan Y, Chen K, Han X. A facile approach to fabrication of bifunctional magnetic-optical $\mathrm{Fe}_{3} \mathrm{O}_{4} @ \mathrm{ZnS}$ microspheres. Chem Mater. 2009;21(20):4892-4898.

4. Liu Y, Yuan M, Qiao L, Guo R. An efficient colorimetric biosensor for glucose based on peroxidase-like protein- $\mathrm{Fe}_{3} \mathrm{O}_{4}$ and glucose oxidase nanocomposites. Biosens Bioelectron. 2014;52:391-396.

5. $\mathrm{Xu} \mathrm{C}$, Xie J, Ho D, et al. $\mathrm{Au}-\mathrm{Fe}_{3} \mathrm{O}_{4}$ dumbbell nanoparticles as dualfunctional probes. Angew Chem Int Ed. 2008;47(1):173-176.

6. Chen W, Yi P, Zhang Y, Zhang L, Deng Z, Zhang Z. Composites of aminodextran-coated $\mathrm{Fe}_{3} \mathrm{O}_{4}$ nanoparticles and graphene oxide for cellular magnetic resonance imaging. ACS Appl Mater. 2011;3(10): 4085-4091.
7. Hayashi K, Ono K, Suzuki H, et al. High-frequency, magneticfield-responsive drug release from magnetic nanoparticle/organic hybrid based on hyperthermic effect. ACS Appl Mater. 2010;2(7):1903-1911.

8. Fukao H, Ikeda M, Ichikawa T, et al. Effect of hyperthermia on the viability and the fibrinolytic potential of human cancer cell lines. Clin Chim Acta. 2000;296(1-2):17-33.

9. Storm FK, Harrison WH, Elliott RS, Morton DL. Normal tissue and solid tumor effects of hyperthermia in animal-models and clinical-trials. Cancer Res. 1979;39(6):2245-2251.

10. Fleet A. Radiobiology for the Radiologist: 6th edition. $J$ Radiother Pract. 2006;5(4):237-237.

11. Suzue K, Zhou X, Eisen HN, Young RA. Heat shock fusion proteins as vehicles for antigen delivery into the major histocompatibility complex class I presentation pathway. Proc Natl Acad Sci U S A. 1997;94(24):13146-13151.

12. Meng H, Xue M, Xia T, et al. Use of size and a copolymer design feature to improve the biodistribution and the enhanced permeability and retention effect of doxorubicin-loaded mesoporous silica nanoparticles in a murine xenograft tumor model. ACS Nano. 2011;5(5):4131-4144.

13. Bae YH, Park K. Targeted drug delivery to tumors: myths, reality and possibility. J Control Release. 2011;153(3):198-205.

14. Matsumura Y, Maeda H. A new concept for macromolecular therapeutics in cancer chemotherapy: mechanism of tumoritropic accumulation of proteins and the antitumor agent SMANCS. Cancer Res. 1986;46 12 Part 1:6387-6392.

15. Low PS. Discovery and development of folic-acid-based receptor targeting for imaging and therapy of cancer and inflammatory diseases. Acc Chem Res. 2008;41(1):120-129.

16. Lee RJ, Huang L. Folate-targeted, anionic liposome-entrapped polylysine-condensed DNA for tumor cell-specific gene transfer. J Biol Chem. 1996;271:8481-8487.

17. Parker N. Folate receptor expression in carcinomas and normal tissues determined by a quantitative radioligand binding assay. Anal Biochem. 2005;338(2):284-293.

18. Park EI, Mi Y, Unverzagt C, Gabius HJ, Baenziger JU. The asialoglycoprotein receptor clears glycoconjugates terminating with sialic acid $\alpha 2,6$ GalNAc. Proc Natl Acad Sci U S A. 2005;102(47): $17125-17129$

19. Zhu M, Diao G. Synthesis of porous $\mathrm{Fe}_{3} \mathrm{O}_{4}$ nanospheres and its application for the catalytic degradation of xylenol orange. J Phys Chem C. 2011;115(39):18923-18934.

20. Zhang H, Zhu G. One-step hydrothermal synthesis of magnetic $\mathrm{Fe}_{3} \mathrm{O}_{4}$ nanoparticles immobilized on polyamide fabric. Appl Surf Sci. 2012; 258(11):4952-4959.

21. Bateer B, Tian C, Qu Y, et al. Facile synthesis and shape control of $\mathrm{Fe}_{3} \mathrm{O}_{4}$ nanocrystals with good dispersion and stabilization. Cryst Eng Comm. 2013;15(17):3366-3371.

22. Hyeon T, Lee SS, Park J, Chung Y, Na HB. Synthesis of highly crystalline and monodisperse maghemite nanocrystallites without a sizeselection process. J Am Chem Soc. 2001;123(51):12798-12801.

23. Daou TJ, Pourroy G, Bégin-Colin S, et al. Hydrothermal synthesis of monodisperse magnetite nanoparticles. Chem Mater. 2006;18(18): 4399-4404.

24. Huang J, Li Q, Li D, et al. Fluxible nanoclusters of $\mathrm{Fe}_{3} \mathrm{O}_{4}$ nanocrystalembedded polyaniline by macromolecule-induced self-assembly. Langmuir. 2013;29(32):10223-102238.

25. Rees RA, Welsh EJ. Secondary and tertiary structure of polysaccharides in solutions and gels. Angew Chem Int Ed. 1977;16(4):214-224.

26. Lian S, Wang E, Kang Z, et al. Synthesis of magnetite nanorods and porous hematite nanorods. Solid State Commun. 2004;129(8):485-490.

27. Sun J, Zhou S, Hou P, et al. Synthesis and characterization of biocompatible $\mathrm{Fe}_{3} \mathrm{O}_{4}$ nanoparticles. J Biomed Mater Res Part A. 2007;80(2): $333-341$.

28. Watthanaphanit A, Supaphol P, Furuike T, Tokura S, Tamura H, Rujiravanit R. Novel chitosan-spotted alginate fibers from wet-spinning of alginate solutions containing emulsified chitosan-citrate complex and their characterization. Biomacromolecules. 2009;10(2):320-327. 
29. Sarangi S, Tan IC, Brazdeikis A. Brownian relaxation of interacting magnetic nanoparticles in a colloid subjected to a pulsatile magnetic field. J Nanosci Nanotechnol. 2011;11(5):4136-4141.

30. Enpuku K, Tanaka T, Matsuda T, et al. Properties of magnetic nanoparticles in the Brownian relaxation range for liquid phase immunoassays. J Appl Phys. 2007;102(5):054910.

31. Mornet S, Vasseur S, Grasset F, Duguet E. Magnetic nanoparticle design for medical diagnosis and therapy. J Mater Chem. 2004;14(14): 2161-2175.

32. Ma M, Wu Y, Zhou H, Sun YK, Zhang Y, Gu N. Size dependence of specific power absorption of $\mathrm{Fe}_{3} \mathrm{O}_{4}$ particles in $\mathrm{AC}$ magnetic field. J Magn Magn Mater. 2004;268(1-2):33-39.

33. Farquhar MG. Recovery of surface-membrane in anterior-pituitary cells - variations in traffic detected with anionic and cationic ferritin. J Cell Biol. 1978;77(3):R35-R42.
34. Mutsaers SE, Papadimitriou JM. Surface-charge of macrophages and their interaction with charged-particles. J Leukoc Biol. 1988;44(1):17-26.

35. Ghinea N, Simionescu N. Anionized and cationized hemeundecapeptides as probes for cell-surface charge and permeability studies - differentiated labeling of endothelial plasmalemmal vesicles. J Cell Biol. 1985; 100(2):606-612.

36. Wilhelm C, Billotey C, Roger J, Pons JN, Bacri JC, Gazeau F. Intracellular uptake of anionic superparamagnetic nanoparticles as a function of their surface coating. Biomaterials. 2003;24(6):1001-1011. 


\section{Supplementary materials}

A

Size distribution by intensity

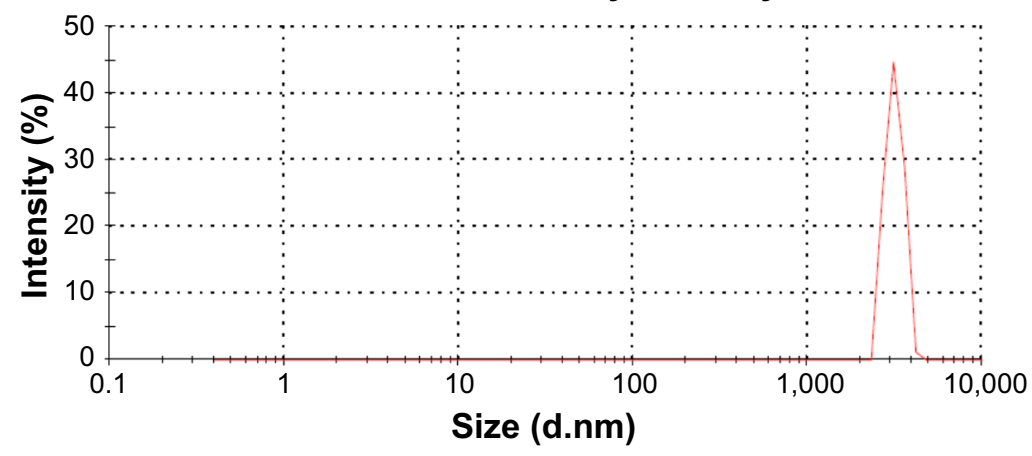

B

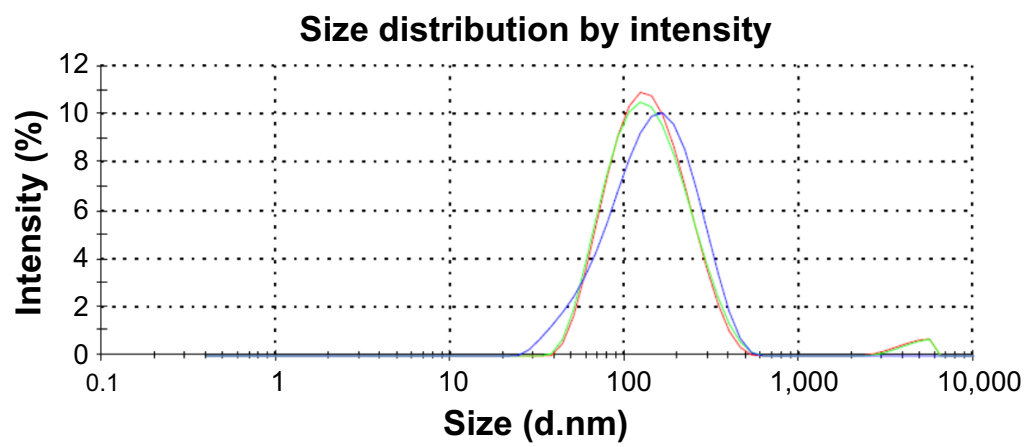

C Size distribution by intensity

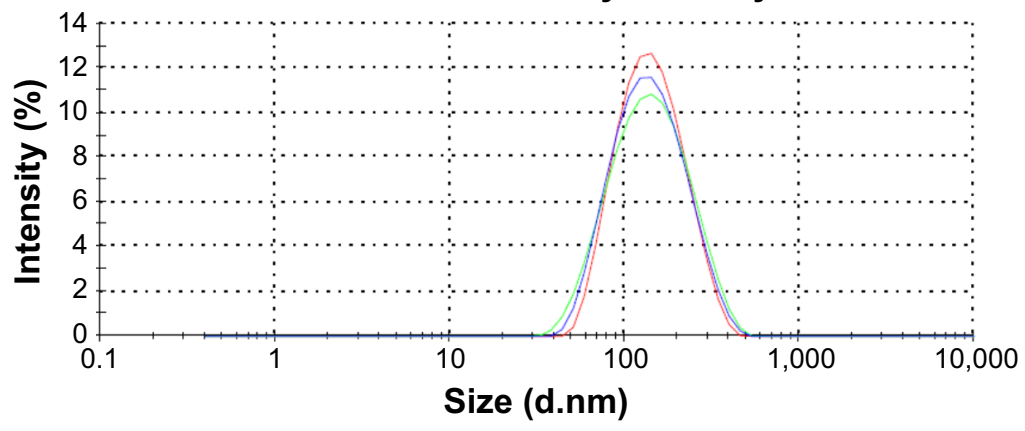

Figure SI Size distribution of $\mathrm{Fe}_{3} \mathrm{O}_{4}(\mathbf{A}), \mathrm{Fe}_{3} \mathrm{O}_{4} @ A l g(\mathbf{B}), \mathrm{Fe}_{3} \mathrm{O}_{4} @ A l g-\mathrm{GA}$ (C).

Table SI Size and PDI of $\mathrm{Fe}_{3} \mathrm{O}_{4} @ \mathrm{Alg}$ nanoparticles according to $\mathrm{pH}$ value and amount of alginate included during synthesis

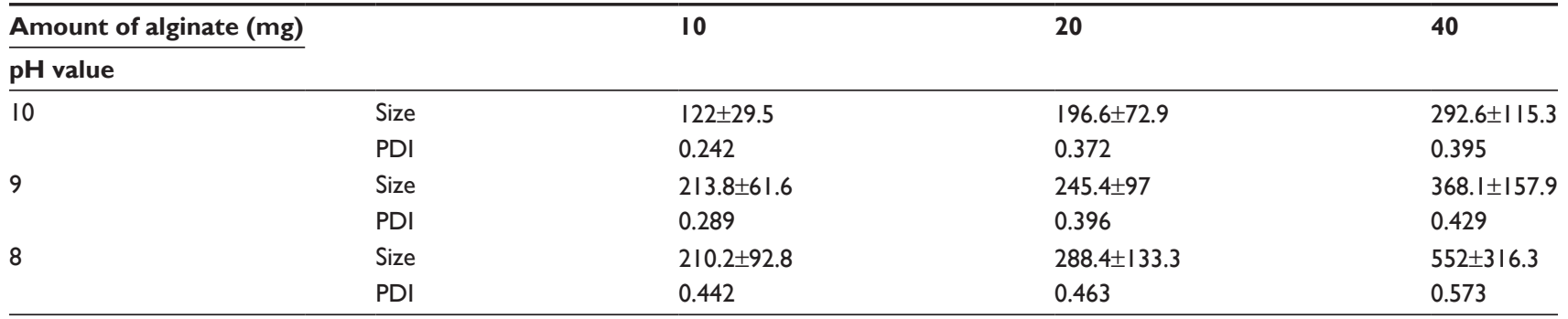

Abbreviation: PDI, polydispersity index 


\section{Publish your work in this journal}

The International Journal of Nanomedicine is an international, peerreviewed journal focusing on the application of nanotechnology in diagnostics, therapeutics, and drug delivery systems throughout the biomedical field. This journal is indexed on PubMed Central, MedLine, CAS, SciSearch $\AA$, Current Contents $\AA /$ Clinical Medicine,

Journal Citation Reports/Science Edition, EMBase, Scopus and the Elsevier Bibliographic databases. The manuscript management system is completely online and includes a very quick and fair peer-review system, which is all easy to use. Visit http://www.dovepress.com/ testimonials.php to read real quotes from published authors.

Submit your manuscript here: http://www.dovepress.com/international-journal-of-nanomedicine-journal 